\title{
ALEXIOS I KOMNENOS AND HIS CHURCH POLICY
}

\author{
Ph.D. Candidate Iakovos MENELAOU, \\ King's College London, \\ UNITED KINGDOM, \\ E-mail: menelaou.iakovos@gmail.com
}

\begin{abstract}
Alexios I Komnenos has been characterized as a gifted military leader. Nevertheless, apart from his military career and after he took the throne, Alexios proceeded to certain measures in order to revive an empire in condition of decline. Alexios established himself as a defender of Orthodoxy, since he helped monasticism, fought heresies and supported the building or renewal of foundations, such as monasteries and churches. In this paper, I deal with Alexios' church policy and how he defended Orthodoxy.
\end{abstract}

Keywords: Komnenoi; Foundations; Monasticism; Diegesis Merike; Dogmatic Panoply;

\section{INTRODUCTION}

Alexios I Komnenos (1057-1118) was son of Ioannis Komnenos and Anna Dalassene. In 1076, he married the daughter of a rich Italian man, but she died one year after their marriage and in 1078, he married Eirene Doukaina with whom he had children. $\mathrm{He}$ became emperor in 1081, but before that he had a significant military career. ${ }^{1}$ Indeed, Alexios was very skillful in military things and had sound knowledge of war techniques. His daughter, Anna Komnene, mentions in the Alexiad his skills and ability in these fields. ${ }^{2}$ According to Magdalino, Alexios was a soldier with simple ideas, ${ }^{3}$ while other descriptions portray him as a military backwoodsman. ${ }^{4}$

In addition, Byzantine seals provide us with further evidence on his military action, as certain inscriptions on seals show that they belong to people that could be identified with some of Alexios' commanders. ${ }^{5}$ Alexios was an outstanding young general, as Frankopan writes, who led a coup against the emperor Nikephoros III Botaneiates. ${ }^{6}$

Alexios' military skills can be also seen in his victorious campaign against Bohemond. The latter had been defeated and forced by Alexios to sign the embarrassing Treaty of Devol. ${ }^{7}$ According to the Treaty, Bohemond would acknowledge Alexios as the

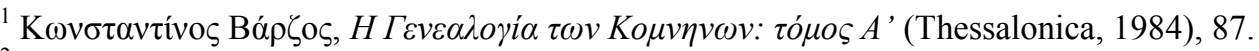

2 Annae Comnenae, Alexias, ed. H.-G. Beck, A. Kambylis, R. Keydell (Berlin 2001).

${ }^{3}$ Paul Magdalino, The Empire of Manuel I Komnenos (Cambridge, 1993), 186.

${ }^{4}$ Margaret Mullett, 'Introduction: Alexios the Enigma', Alexios I Komnenos Papers, edited by Margaret Mullett and Dion Smythe (Belfast, 1996), 1-11.

${ }^{5}$ Vujadin Ivanisevic and Bojana Krsmanovic, 'Byzantine Seals from the Ras Fortress', Recueil des Travaux de l'Institut d'études Byzantines L, 2013, 449-460. See also Ivan Jordanov, 'Seals of the Personages from the Alexiad Found in Veliki Preslav', Vestnik Volgogradskogo Gosudarstvennogo Universiteta. Seriâ 4. Istoriâ, Regionovedenie, Meždunarodnye Otnošeniâ 2016; 21, 19-31.

${ }^{6}$ Peter Frankopan, 'Kinship and the Distribution of Power in Komnenian Byzantium', The English Historical Review, Vol. 122, No 495 (2007), 1-34.

${ }^{7}$ Nicholas L. Paul, 'A Warlord's Wisdom: Literacy and Propaganda at the Time of the First Crusade', Speculum, Vol. 85, No. 3 (2010), 534-566.
} 
lord of the lands he conquered in Syria and he would never challenge Byzantine authority in the future. ${ }^{8}$ According to Frankopan, Bohemond was a great propagandist against Alexios. He attracted followers with stories of his exploits and urged his people to take the Cross and set out for Jerusalem, but attacking the emperor of Constantinople first. In order to justify action against fellow Christians, he sent a letter to the Pope underlining a long list of supposed heresies perpetrated by the Orthodox Church. ${ }^{9}$

Also, in 1090s, Alexios turned to the recovery of Anatolia, while a number of Aegean islands, Cyprus and Crete were recaptured in 1092. ${ }^{10}$ The recovery of Western Anatolia was an attempt greatly assisted by the passing of the armies of the First Crusade through Anatolia in 1097 . $^{11}$

However, apart from these references to his military skills, as we are going to see Alexios was also a benefactor of the Orthodox Church during his reign. One could say that Alexios helped the Church and was a defender of Orthodoxy. As Armstrong states, Alexios was close to holy-men and monasticism because of political reasons, ${ }^{12}$ but still his contribution is very important.

According to Pentcheva, in 1081, Alexios succeeded the Macedonian dynasty which brought a chaos in the empire, rejected the civil aristocracy and established his family as the new dynasty. Alexios promoted a campaign in defense of Orthodoxy and attacked heretical movements, although sometimes Orthodoxy had been used as an excuse for the condemnation of his political enemies. In addition, his dynasty promoted the new image-type icon of the orans Virgin with the hovering medallion, since it was seen as an expression of the dogma of the Incarnation and Orthodoxy. ${ }^{13}$

Alexios' reign could be seen as a decisive change in the system of government, attracting the interest of several Byzantinists. His reign suggested new policies, social, political and economic changes, while it was also a critical crossing between east and west. ${ }^{14}$ Frankopan declares that Alexios' government was significantly based on domestic politics, as Alexios appointed his confidants and supporters to the highest positions, while he used his family as a protective ring around himself, showing some sort of overwhelming control. ${ }^{15}$ It could be said that Alexios' church policy encouraged other members of the family to support Orthodoxy. There are several monastic establishments set up by members of the imperial family, like the church and monastery of the Saviour Pantepoptes established by Anna

\footnotetext{
${ }^{8}$ Paul, ‘A Warlord's Wisdom', 537.

${ }^{9}$ Peter Frankopan, The First Crusade (Harvard, 2012), 189.

${ }^{10}$ Jason T. Roche, 'In the Wake of Mantzikert: The First Crusade and the Alexian Reconquest of Western Anatolia', History, Vol. 94, No. 2 (314) (2009), 135-153.

${ }^{11}$ Roche, 'In the Wake of Mantzikert', 145.

12 Pamela Armstrong, 'Alexios I Komnenos, Holy Men and Monasteries', Alexios I Komnenos Papers, edited by Margaret Mullett and Dion Smythe (Belfast, 1996), 219-231.

${ }^{13}$ Bissera V. Pentcheva, 'Rhetorical Images of the Virgin: The Icon of the "Usual Miracle" at the Blachernai', RES: Anthropology and Aesthetics No. 38 (Autumn, 2000), 34-55.

${ }_{15}^{14}$ Frankopan, 'Kinship and the Distribution of Power in Komnenian Byzantium', 1.

15 Frankopan, 'Kinship and the Distribution of Power in Komnenian Byzantium', 2-3, 7. Frankopan gives a detailed description on how members of the Komnenian family were involved in the government. Apart from the Alexiad, there is another source dealing with the dynasty. This is John Zonaras' Epitome Historion, which gives an explicit commentary on Alexios and the whole family. For example, both sources give an extensive commentary on Anna Dalassene's powers and responsibilities, when Robert Guiscard attacked the empire in the early 1080s.
} 
Dalassene, or the Kosmoteira monastery of the Mother of God founded by Alexios' son, Isaac Komnenos. ${ }^{16}$

\section{FOUNDATIONS AND MONASTICISM}

In the Alexiad, Anna Komnene gives a detailed description of Orphanotropheion, focusing on the philanthropic aspect of her father's character. ${ }^{17}$ Orphanotropheion had been reconstituted after the latter's initiative and it was not only a place for orphan children, but a place for poor people too. Although founded by Justin II, Alexios renovated the building. ${ }^{18}$ Magdalino describes Orphanotropheion as 'a second city within the royal city', drawing a parallel with oikos; a building of Constantine IX Monomachos which consisted of a palace, a monastery, a law-school, poor-houses, old-age homes, hostels and a hospital. ${ }^{19}$

Apart from Orphanotropheion, Alexios proceeded with other foundations. Although the idea of the foundation of Christ Philanthropos and Theotokos Kekharitomene belongs to his wife, in fact Alexios supported these foundations. ${ }^{20}$ As Choniates declares, this double monastery was a foundation by Alexios himself based on the fact that the emperor had been buried there and it was a clearly Komnenian foundation. ${ }^{21}$ Also, according to an epigram, Alexios was among the benefactors of the monastery of Mokios. Although the epigram connects the building of the monastery to Manuel, Alexios was a great patron who established a community of monks. ${ }^{22}$ Similarly, while Blachernai palace was a foundation before Alexios' reign, ${ }^{23}$ he renewed Blachernai church, because of a miraculous icon of the Virgin that was rediscovered. ${ }^{24}$ As Cotsonis asserts, by the eleventh century, all the levels of society turned to images for guidance and devotion and Alexios was such an example. He turned to the habitual or usual miracle, involving this Marian icon in the church of Blachernai. $^{25}$

Magdalino declares that Alexios supported monasticism, while Hagia Sophia emerged in Alexios' years and played a permanent role in the twelfth-century Church. In

\footnotetext{
${ }^{16}$ Frankopan, The First Crusade, 72. See also Charalambos Bakirtzis, 'Warrior Saints or Portraits of Members of the Family of Alexios I Komnenos?', British School at Athens Studies, Vol. 8, Mosaic: Festschrift for A. H. S. Megaw (2001), 85-87. Bakirtzis focuses on the programme of iconography in the church of the Panaghia Kosmosoteira that presents certain distinctive figures, reflecting the wishes of Isaac Komnenos, who was the founder.

${ }^{17}$ Comnenae, Alexias.

${ }^{18}$ Lyn Rodley, 'Tha Art and Architecture of Alexios I Komnenos', Alexios I Komnenos Papers, edited by Margaret Mullett and Dion Smythe (Belfast, 1996), 339-358.

${ }_{19}^{19}$ Magdalino, The Empire of Manuel I Komnenos, 115.

${ }^{20}$ Michael Angold, Church and Society in Byzantium Under the Comneni, 1081-1261 (Cambridge, 1995), 274. The typikon of the foundation of the monastery should be read as a careful selection of whom the empress Eirene though deserved prayer and who she did not. Thus, it is not a surprise that there is no mention of Adrian, Alexios' younger brother, as he plotted against him. In any case, Kekharotimene is a prime example of official Komnenian history and image (Frankopan, 'Kinship and the Distribution of Power in Komnenian Byzantium', 31-32).

${ }^{21}$ Rodley, 'Tha Art and Architecture of Alexios I Komnenos', 344-345.

22 Rodley, 'Tha Art and Architecture of Alexios I Komnenos', 345.

${ }^{23}$ Rodley, 'Tha Art and Architecture of Alexios I Komnenos', 347.

${ }^{24}$ Magdalino, The Empire of Manuel I Komnenos, 116.

25 John Cotsonis, 'Narrative Scenes on Byzantine Lead Seals (Sixth-Twelfth Centuries): Frequency, Iconography, and Clientele', Gesta, Vol. 48, No. 1 (2009), 55-86. It is also interesting to note, that as Cotsonis writes, in the Alexiad, Anna Komnene writes that while her father was absent from the capital in August, her grandmother, Anna Dalassene, issued a seal with images of the Transfiguration and the Dormition, as they were both major liturgical celebrations of that month.
} 
addition, he sponsored the monastery of Patmos. ${ }^{26}$ Indeed, the monastery of Patmos was a basic factor in links between Constantinople and other Christian communities, like these of Syria and Palestine. ${ }^{27}$

Commenting on the patronage of literature, Mullett declares that Alexios was not a renowned patron of the different genres. Nevertheless, it is interesting to note that there might have been some use of hymnography and hagiography and there were several holy men under Alexios' reign. ${ }^{28}$ Alexios has been characterized as philomonahos, because of his strong relationship with Cyril Phileotes. Alexios cared indeed about monks and hermits and saw them as representatives of God on the land. The fact that he visited Cyril Phileotes twice, between 1091-1096 and in 1105, shows his interest in the monastic community. ${ }^{29}$ Alexios followed the route of his mother, as Anna Dalassene also appreciated the role of monasticism. After she read about Cyril Phileotes, she wanted to meet him. Apart from gifts and offers to the monk, Dalassene asked his blessing. ${ }^{30}$

Similarly to his mother, when Alexios heard about Cyril Phileotes, he wanted to meet him too. Langis provides us with interesting information about the attitude of the emperor during this meeting, as he only sat when the monk told him to do so. Alexios mentioned that it was God who trusted him to rule the empire, while respecting monks is among his responsibilities, as monks serve God and they deserve praise and compliments. ${ }^{31}$

On the other hand, Cyril Phileotes could see that Alexios was truly philomonahos. When the emperor would fight Franks, Cyril prayed for Alexios' victory. He also gave him his blessing and had a dream about the fight. ${ }^{32}$ We should bear in mind also, that when Alexios visited Cyril Phileotes, the latter praised him for his social and religious work, stressing Orphanotropheion. ${ }^{33}$

Alexios helped hermits and monasteries in other ways too: by giving food, clothes and all the necessary equipment. ${ }^{34}$ His respect to monks and his active role in monastic life shows his positive contribution to monasticism. When Alexios learnt that Cyril Phileotis was sick, he decided to visit him again, this time with his whole family. In the meantime, Alexios considered the monk the only person who could tell him the right route to defeat Turks. ${ }^{35}$

In 1096, in order to improve the condition of the monasteries and other buildings, Alexios proceeded to certain decisions. Thus, he provided the Patriarch with the right of epiteresis (oversight) and diorthosis (correction) over all the Church's buildings, while at the same time the Patriarch could visit any building to inspect for possible faults. In addition, the monasteries were given an epidosis (financial benefits) and the Patriarch had the right to ask from their holders to restore damages. ${ }^{36}$

Although kharistike was a measure that prevailed before his reign, Alexios kept it. Kharistike was the lay patronage of the monasteries and kharistikarioi were in charge of the

\footnotetext{
${ }^{26}$ Magdalino, The Empire of Manuel I Komnenos, 318.

${ }^{27}$ Rosemary Morris, Monks and Laymen in Byzantium: 843-1118 (Cambridge, 1995), 272.

${ }^{28}$ Margaret Mullett, 'The Madness of Genre', Dumbarton Oaks Papers, Vol. 46 Homo Byzantinus: Papers in Honor of Alexander Kazhdan (1992), 233-243.

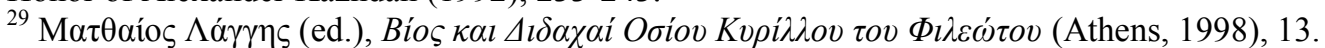

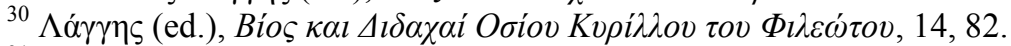

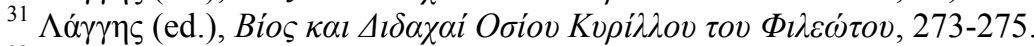

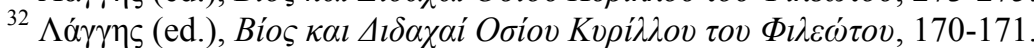

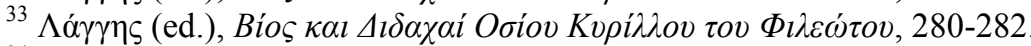

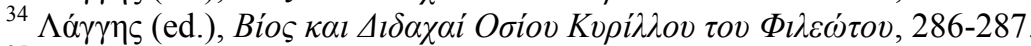

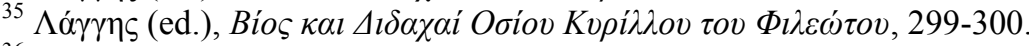

${ }^{36}$ Morris, Monks and Laymen in Byzantium, 274.
} 
monasteries' protection. However, Alexios saw after consultation with the Patriarch Nicholas Grammatikos, that he should proceed to some changes in order to reduce the likelihood of monasteries' abuse by their patrons, as -very frequently- they were independent and treated monasteries without the proper respect. Consequently, Alexios established lay archontes at large monasteries, since monks should be devoted to their divine action and their duties should be primarily ecclesiastical. ${ }^{37}$

As measure, kharistike gave lay patrons not only the right to access monasteries, but establish themselves. Monasteries became independent, and the patrons had nobody to supervise their action. Inevitably, there were people close to the Church who could not accept this situation. John of Oxeia attacked kharistike, mentioning that lay patronage caused several problems to monasteries. His purpose was the improvement and control of monasteries' condition. According to John of Oxeia, patrons treated monasteries unacceptably and this should change. ${ }^{38}$

In 1096, Nicholas Grammatikos set up a commission consisting of deacons and officers, intending to visit monasteries and see their condition. Nevertheless, kharistikarioi did not allow them to access the houses, and possible abuses remained unrevealed. Thus, the members of the commission returned to the emperor, and asked him if they had, really, the right to access the monasteries. Alexios ordered that abbots or lay patrons who were guilty for trading and abuse in the monasteries should be dismissed. Also, he commissioned the Patriarch to create adelphata (corrodies) in the monasteries to supervise the condition of the monasteries more effectively. ${ }^{39}$

\section{DIEGESIS MERIKE}

Diegesis merike is a collection of letters compiled in Constantinople in 1180 and it deals with some problems on Mount Athos in the eleventh and twelfth centuries. ${ }^{40}$ Diegesis merike is a useful source on some further measures by Alexios. We should focus on three specific scandals taking place on Mount Athos: the first one is a demand by the hegoumenos of Lavra, John Balmas, with a group of monks for the removal of Vlach herdsmen from the mountain. The second one is some monks' complaints about the presence of children and eunuchs on the mountain; and finally the case of Symeon the Sanctified who return to the mountain after Alexios' intervention. ${ }^{41}$

John Balmas reacted, because Vlach herdsmen used to live on the mountain with their families. Although some monks welcomed Vlachs at the end of the eleventh century, another group of monks under the orders of the hegoumenos of Lavra complained to the Patriarch Nicholas Grammatikos. The Patriarch did not order the removal of Vlachs and then Balmas issued a forged patriarchal entole, that monks must force the herdsmen to leave. When Alexios heard about this, he asked John Chortaitinos to investigate the case. However the latter refused to do that, because the Patriarch was in his deathbed and was afraid of his curse. The case ended after Balmas, who also heard about the physical condition of Nicholas Grammatikos, revealed the true event. ${ }^{42}$

\footnotetext{
${ }^{37}$ Morris, Monks and Laymen in Byzantium, 274.

${ }^{38}$ Angold, Church and Society in Byzantium, 65.

${ }^{39}$ Angold, Church and Society in Byzantium, 64-65.

${ }^{40}$ Morris, Monks and Laymen in Byzantium, 275.

${ }^{41}$ Morris, Monks and Laymen in Byzantium, 279.

${ }^{42}$ Morris, Monks and Laymen in Byzantium, 275-278.
} 
As Gkoutzioukostas writes, frequently the emperor appointed commissioners to hear cases and then sign any decisions. Such an example is Alexios' chrysobullos logos (1084), according to which the emperor gave authority to the protoanthypatos and krites of the hippodrome, Michael Rhodios, to investigate the dispute between the Great Lavra Monastery and the emperor's brother, the pansebastos protosebastos Adrianos. The judge of the hippodrome wrote a synopsis of his decision; a parasemeiosis. Then the monks asked the emperor to give formal consent to this decision with a chrysobullos logos securing their rights. $^{43}$ Michael Rhodios' story is an interesting one, as he is mentioned in other contemporary documents like krites of Boleron, Strymon and Thessalonike. In fact, he is cited in a chrysobull of Alexios dated in July 1104, because the emperor commissioned him to settle a land dispute. ${ }^{44}$

Although Diegesis merike does not show the Patriarch issuing a formal order, there is evidence in a document from the Archives of the Protaton, dated between 1178-9 that refers to a monk who left the monastery, because of Grammatikos' prohibition on mixing between Vlachs and the rest of monks. But even if we consider that the Patriarch issued, indeed, this kind of entole, Alexios showed his opposition to the removal of Vlachs and requested further investigation. $^{45}$

Second, the appearance of children and eunuchs on the mountain caused the reaction of some monks who complained to the emperor. Alexios rejected their suggestion and he called them 'false hesychasts', as they left their monasteries without permission from the protos. In addition, Alexios informed the Patriarch on this event. ${ }^{46}$

Finally, Symeon the Sanctified had been removed from Mount Athos, but the emperor ordered his immediate reinstatement. As a result, the protos, although reluctantly, accepted Symeon back. In fact, Alexios was very close to Symeon, as the latter worked for the emperor when he was still megas domesikos. The relationship between the two men was a basic reason for Alexios to order Symeon's return to Athos. ${ }^{47}$

\section{AGAINST HERESIES}

The trial of John Italos in 1082 was an important step against heresies. ${ }^{48}$ For Alexios, mystical teachings and theories were a great threat for the Church, and the content of Italos' theory was such a teaching. By condemning John Italos, Alexios showed that he would not accept any teachings undermining Orthodoxy. It is interesting to note, that he also added new anathemata to the synodikon (statement of faith against heresies) condemning Italos and his pupils. $^{49}$ This new addition should be seen as a way to fight particularly Italos. Anna Komnene gives a very interesting description of John Italos in the fifth book of her Alexiad. She declares that he did not read philosophy in depth and he did not have learned teachers

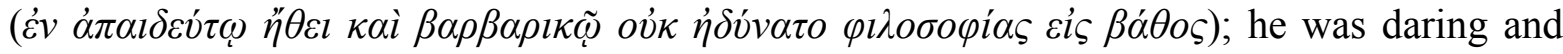

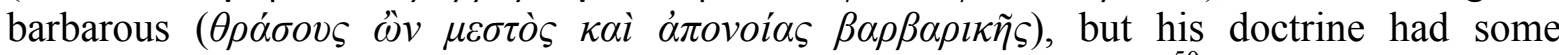
popularity during these years, causing some turbulence in the Church. ${ }^{50}$

\footnotetext{
${ }^{43}$ Andreas Gkoutziokostas, "Judges of the Velum" and "Judges of the Hippodrome" in Thessalonike (11th c.)', Byzantina Symmeikta Vol. 20, 2010, 67-84.

${ }^{44}$ Gkoutziokostas, "Judges of the Velum" and "Judges of the Hippodrome" in Thessalonike (11th c.)', 76.

${ }^{45}$ Morris, Monks and Laymen in Byzantium, 275-278.

${ }^{46}$ Morris, Monks and Laymen in Byzantium, 278.

${ }^{47}$ Morris, Monks and Laymen in Byzantium, 280.

${ }^{48}$ Angold, Church and Society in Byzantium, 50.

${ }^{49}$ Angold, Church and Society in Byzantium, 51-52.

${ }^{50}$ Comnenae, Alexias, 161-162.
} 
Pentcheva declares that John Italos was responsible for the education of the elite class. By presenting himself as a guardian of Orthodoxy, he attempted to establish a programme for the legitimacy of the dynasty. Among others, John Italus was accused of introducing Neoplatonic logic to explain the Orthodox mysteries, like the Incarnation. He was condemned as unorthodox and the last session in his trial book took place on the Sunday of the Feast of Orthodoxy, which celebrates the victory over Iconoclasm in $843 .{ }^{51}$ After his statements were anathematized, they were included in the list of heresies in the Synodikon of Orthodoxy. ${ }^{52}$ By setting the trial and condemning John Italos, Alexios presented himself as a defender of Orthodoxy 'from the rank of the famous iconophiles of the past'. ${ }^{53}$

If the heresy of Italos could only be seen as a pretext for a politically motivated trial, the case was different for the Bogomils, as Pentcheva claims. According to Bogomils, the material world was created by the fallen son of God, Satanael, and Christ, God's other son, brought the possibility of salvation. ${ }^{54}$ They declared that Christ was not incarnate in the Virgin, but he crept through her right ear and put on a body that seemed physical. Then, he went out again and was found laying in the crib. Consequently, by refusing the dogma of the Incarnation, the Bogomils constituted a real threat and they were rejected in the Synodikon of Orthodoxy. ${ }^{55}$

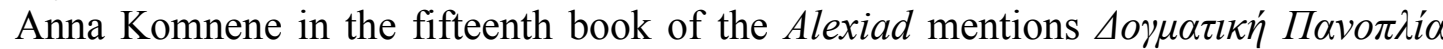
(Dogmatic Panoply), as Alexios' basic way to fight heresies in Byzantium. His decision to proceed to this measure could be seen as a decisive step to keep the authority of Orthodoxy. Although Anna connects the Dogmatic Panoply mainly to the Bogomils, in fact Alexios intended to eliminate other heresies too. ${ }^{56}$ As Magdalino mentions, Alexios commissioned the monk Euthymios Zigabenos to compile the Dogmatic Panoply, against heresy in general. That was an attempt to attack and eliminate doctrinal outsiders, such as Jews, Muslims, Bogomils, Paulicians, and Monophysite Syrians. ${ }^{57}$

Anna Komnene characterizes Basil, the leader of the Bogomils, as disregardful ( $\dot{\alpha} \sigma \varepsilon \beta \dot{\eta} \varsigma)$, giving some details of Basil's and his pupils' persecution by her father. Anna describes Basil as a person who tried to corrupt the ideals of Christianity, through his teaching. Although initially she states that she feels shame to speak about a topic like that, she considers necessary to refer to the basic elements of this heresy. As a result, Alexios' decision for Basil's $\kappa \alpha \theta \alpha i \rho \varepsilon \sigma \iota \varsigma$ (dismissal) was a right one, according to Anna. ${ }^{58}$ After Basil's trial in 1097 and because Basil did not recant his beliefs, he was burnt on the pyre in Constantinople. While this public condemnation intended to undermine the influence of the Bogomils, Alexios' political power was strengthened, as well. ${ }^{59}$

\footnotetext{
${ }^{51}$ Pentcheva, 'Rhetorical Images of the Virgin', 50.

52 Pentcheva, 'Rhetorical Images of the Virgin', 50.

${ }^{53}$ Pentcheva, 'Rhetorical Images of the Virgin', 50.

${ }^{54}$ Pentcheva, 'Rhetorical Images of the Virgin', 51.

${ }^{55}$ Pentcheva, 'Rhetorical Images of the Virgin', 51. Genre', 238-239).

${ }^{57}$ Magdalino, The Empire of Manuel I Komnenos, 367.

${ }^{58}$ Comnenae, Alexias, 489.

${ }^{59}$ Pentcheva, 'Rhetorical Images of the Virgin', 51.
}

${ }^{56}$ Comnenae, Alexias. According to Mullett, Alexios was not known for his patronage of literature, although more recent research attempts to show a different version. However, he commissioned others to produce certain writings: an alphabet by Stephen Physopalamites, Euthymios Zigabenos' Dogmatic Panoply and some conventional occasional poetry by Nicholas Kallikles, a court poet. It is also interesting to note the Mousai, which was his own composition of paraineseis in dodecasyllables for his son John (Mullett, 'The Madness of 
Before the death of his brother, the sebastocrator Isaac in 1102, Alexios established the preachers' order (didaskaloi), intending to attack the heresy of the Bogomils. According to Angold, Alexios' measure diverged from the initial plan, as didaskaloi's duties were mainly academic and not pastoral. ${ }^{60}$ Furthermore, Magdalino expresses a similar view, declaring that didaskalos ton ethnon failed to supervise the catechism to Christianity. ${ }^{61}$ In any case, one would say that the protection of Orthodoxy was a priority for Alexios. Apart from the Dogmatic Panoply, he added anathemata to synodikon, strengthening his persecutions against heretics. The condemnation of Basil the Bogomil and John Italos could be seen as evidence that Alexios defended the authority of the Orthodox Church vigorously.

\section{Criticism}

When Alexios would fight Normans in 1081, he ordered the confiscation of the Church's treasures for the financial support of this war. Although he asked the opinion of holy men and spiritual people, the reaction came from the official Church and was led by the Bishop of Chalcedon, Leo. Leo accused the Patriarch, considering him responsible for the confiscation of the Church's treasures. Leo continued his attack, asserting that Garidas was connected to Messalianism. Although the Patriarch was innocent, Alexios replaced him with Nicholas Grammatikos, but still Leo was dissatisfied. It could be said that the real reason for Leo's reaction was his opposition to Alexios' policy in general. The confiscation of the Church's treasures was only one reason, as Leo was a permanent opponent of the emperor's policy. The result of this contradiction was finally, the synod of Blachernai in 1094 that confirmed Alexios' victory, while Leo had been exiled. ${ }^{62}$

As Pentcheva writes, in the theological writings of Leo one can see the idea of empsychos graphe. Leo expresses a very radical position on religious representation, while his defense of images was prompted by his contradiction with Alexios that lasted from 1082 to 1094. Leo opposed Alexios' policy of raising funds for military purposes by means of confiscation of Church's property. Although Leo's statements were meant to protect Church property, his views were very extreme and reflected a particular trend towards the veneration of the images. ${ }^{63}$ As Frankopan states, in 1082 Alexios swore on oath that he would never take treasures from the Church again, but three years later he took precious ecclesiastical objects, breaking his promise. This Alexios' decision caused a furious reaction against him, although his daughter, Anna, attempts to defend him. ${ }^{64}$

John Oxeites, who -as we have seen- showed his opposition to Alexios' lay patronage and kharistike, was another of Alexios' greatest enemies. In 1091, Alexios called a Council for contributions from the church in order to face the Pecheneg invasion. John presented a memorandum, asserting that any disasters in the empire constitute divine punishment, because of Alexios' sinful administration. ${ }^{65}$

\footnotetext{
${ }^{60}$ Angold, Church and Society in Byzantium, 60.

${ }^{61}$ Magdalino, The Empire of Manuel I Komnenos, 326.

${ }^{62}$ Angold, Church and Society in Byzantium, 46.

${ }^{63}$ Pentcheva, 'Rhetorical Images of the Virgin', 43. In relation to that, Cotsonis focuses on two seals depicting Anna Komnene and her husband, Nikephoros Bryennios, and sets the questions why these two saw inscriptions as denoting greater personal piety than figural imagery. Vitalien Laurent suggests, as Cotsonis writes, that this practice, appearing in the late eleventh and twelfth centuries, reflected the debate over images between Alexios and Leo (Cotsonis, 'Narrative Scenes on Byzantine Lead Seals', 69).

${ }^{64}$ Frankopan, The First Crusade, 72.

${ }^{65}$ Magdalino, The Empire of Manuel I Komnenos, 269.
} 
Nevertheless, Theophylact, Archbishop of Ohrid, was a great supporter of Alexios' military profile and policy and belonged to Alexios' circle. The emperor commissioned him to collect the kanonikon; a tax that should be paid by the clergy and the laity to the Bishop. Because of some difficulties in collecting, Alexios issued a prostagma authorizing Theophylact in charge. ${ }^{66}$

Theophylact was against the emperors who followed unmilitary policy. This is why he praises Alexios' decision to adopt a different, military policy and he also celebrates his military prowess, bravery, prudence, philanthropy and mildness in his speeches. ${ }^{67}$ Theophylact compares Alexios to his predecessors, concluding that Alexios showed that he is more competent than them. Also, in his encomium to Alexios, Theophylact refers to the common action of the emperor with his mother, Anna Dalassene, stating that it was very advantageous for the empire. ${ }^{68}$ As opposed to John Oxeites and Leo who criticized the emperor's policy, Theophylact praises Alexios' skills, similarly to Cyril Phileotes, who also mentions Alexios' social and religious work. ${ }^{69}$

\section{CONCLUSION}

In general, defending Orthodoxy was a priority in Byzantine Empire. Byzantium saw itself as the Oecumene, the Orthodox Empire that promoted right-thinking Christianity. ${ }^{70}$ As Davies asserts 'the state and the church were fused into one indivisible whole...'; this suggested a kind of Caesaropapism which had no equal in the West. ${ }^{71}$ In fact, according to Treadgold, Byzantium lives in the Eastern Orthodox Church and its devotion, rituals and mysticism. ${ }^{72}$ This could not be different for Alexios, as he saw himself as a defender of Orthodoxy. ${ }^{73}$ Besides, within the empire, Orthodoxy was dominant from cultural and political perspective. ${ }^{74}$ Constantinople had many hundreds of churches and monasteries, since the Byzantine Empire was founded on a strong Christian culture. ${ }^{75}$ Alexios' measures to defeat certain heresies and other decisions he made to help the Church established the idea that Komnenoi were the guardians of Orthodoxy. Apart from any political power and authority defining him as the supreme political leader, the emperor was the chosen one and

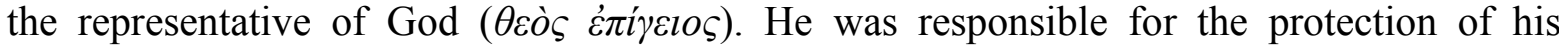

\footnotetext{
${ }^{66}$ Angold, Church and Society in Byzantium, 61.

${ }^{67}$ Magdalino, The Empire of Manuel I Komnenos, 419.

${ }^{68}$ Magdalino, The Empire of Manuel I Komnenos, 422.

${ }^{69}$ According to Frankopan, John Komnenos plotted against his uncle, with his motivations being unclear. The one who informed Alexios about this John's conspiracy was Theophylact of Ohrid (Frankopan, 'Kinship and the Distribution of Power in Komnenian Byzantium', 16).

${ }^{70}$ Steven Runciman, 'Byzantium, Russia and Caesaropapism', Canadian Slavonic Papers / Revue Canadienne des Slavistes, Vol. 2 (1957), 1-10.

${ }^{71}$ Norman Davies in Warren Treadgold, 'The Persistence of Byzantium', The Wilson Quarterly (1976), Vol. 22, No. 4 (1998), 66-91.

72 Treadgold, 'The Persistence of Byzantium', 67.

73 Pentcheva, 'Rhetorical Images of the Virgin', 51.

74 Aristotle Papanikolaou, 'Byzantium, Orthodoxy, and Democracy', Journal of the American Academy of Religion, Vol. 71, No. 1 (2003), 75-98.

75 Jonathan Harris, The End of Byzantium (Yale, 2010), 24.
} 
subjects, the Church and the Christian religion. ${ }^{76}$ Even a war should be seen as a decision of the emperor to protect the Church and Christians. ${ }^{77}$

Foundations such as Orphanotropheion, Christ Philanthropos and Theotokos Kekharitomene, the monastery of Mokios and Blachernai church which are either renewed or founded during Alexios' reign show his intention to be a defender of Orthodoxy. By reconstructing Orphanotropheion, Alexios helped church communities, monastic communities and disadvantaged people. Other buildings, like Christ Philanthropos and Theotokos Kekharitomene could be also seen as an attempt of his to help these communities.

His relationship with Cyril Phileotes is also proof of his contribution to Orthodoxy.

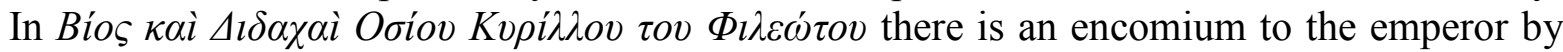
the monk, praising his social and religious work. There are at least two references to Alexios as philomonahos:

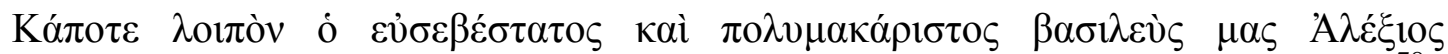

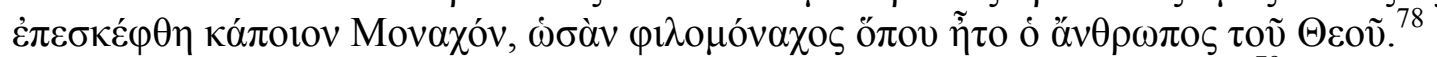

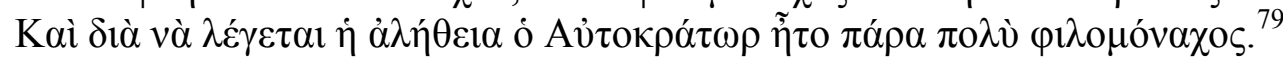

Indeed, Alexios saw monks as people with spiritual power. The fact that he asked Cyril's advice before his attack to Franks shows his appreciation and respect. In addition, the responsibilities given to Patriarch (epiterisis and diorthosis) could be seen as Alexios' measures to benefit monasteries. Although John Oxeites reacted to Alexios' kharistike, one should also note that Alexios' target was to reinforce the role of monasteries, while the Dogmatic Panoply was a certain way to keep the authority of the Church unaffected by the action of certain heresies.

\section{BIBLIOGRAPHY}

[1] Angold, M., Church and society in Byzantium under the Comneni: 1081-1261 (Cambridge, 1995).

[2] Armstrong, P., 'Alexios I Komnenos, Holy Men and Monasteries', Alexios I Komnenos Papers, edited by Margaret Mullett and Dion Smythe (Belfast, 1996), 219-231.

[3] Bakirtzis, C., 'Warrior Saints or Portraits of Members of the Family of Alexios I Komnenos?', British School at Athens Studies, Vol. 8, Mosaic: Festschrift for A. H. S. Megaw (2001), 8587.

[4] Comnenae, A., Alexias, ed. H. -G. Beck, A. Kambylis, R. Keydell (Berlin, 2001).

[5] Cotsonis, J., 'Narrative Scenes on Byzantine Lead Seals (Sixth-Twelfth Centuries): Frequency, Iconography, and Clientele', Gesta, Vol. 48, No. 1 (2009), 55-86.

[6] Frankopan, P., 'Kinship and the Distribution of Power in Komnenian Byzantium', The English Historical Review, Vol. 122, No 495 (2007), 1-34.

[7] Frankopan, P., The First Crusade (Harvard, 2012).

[8] Gkoutziokostas, A., "Judges of the Velum" and "Judges of the Hippodrome" in Thessalonike (11th c.)', Byzantina Symmeikta Vol. 20, 2010, 67-84.

[9] Harris, The End of Byzantium (Yale, 2010).

[10] Ivanisevic, V. and Krsmanovic, B., 'Byzantine Seals from the Ras Fortress', Recueil des travaux de l'Institut d'études byzantines L, 2013, 449-460.

[11] Jordanov, I., 'Seals of the Personages from the Alexiad Found in Veliki Preslav', Vestnik Volgogradskogo Gosudarstvennogo Universiteta. Seriâ 4. Istoriâ, Regionovedenie, Meždunarodnye Otnošeniâ 2016;21, 19-31.

\footnotetext{
${ }^{76}$ Athina Kolia-Dermitzaki, "'Holy War” In Byzantium Twenty Years Later: A Question of TermDefinition and Interpretation', Byzantine War Ideology Between Roman Imperial Concept and Christian Religion, edited by Johannes Koder and Ioannis Stouraitis (Vienna, 2012), 120-132.

${ }^{77}$ Kolia-Dermitzaki, “'Holy War” In Byzantium Twenty Years Later', 122.

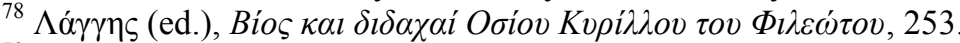

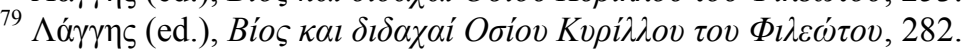


[12] Kolia-Dermitzaki, A., "Holy War" In Byzantium Twenty Years Later: A Question of TermDefinition and Interpretation', Byzantine War Ideology Between Roman Imperial Concept and Christian Religion, edited by Johannes Koder and Ioannis Stouraitis (Vienna, 2012), 120-132.

[13] Mullett, M., 'The Madness of Genre', Dumbarton Oaks Papers, Vol. 46 Homo Byzantinus: Papers in Honor of Alexander Kazhdan (1992), 233-243.

[14] Magdalino, P., The Empire of Manuel Komnenos: 1143-1180 (Cambridge, 1993).

[15] Morris, R., Monks and Laymen in Byzantium: 843-1118 (Cambridge, 1995).

[16] Mullett, M., 'Introduction: Alexios the Enigma', Alexios I Komnenos papers, edited by Margaret Mullett and Dion Smythe (Belfast, 1996), 1-11.

[17] Papanikolaou, A., 'Byzantium, Orthodoxy, and Democracy', Journal of the American Academy of Religion, Vol. 71, No. 1 (2003), 75-98.

[18] Paul, N. L., 'A Warlord's Wisdom: Literacy and Propaganda at the Time of the First Crusade', Speculum, Vol. 85, No. 3 (2010), 534-566.

[19] Runciman, S., 'Byzantium, Russia and Caesaropapism', Canadian Slavonic Papers / Revue Canadienne des Slavistes, Vol. 2 (1957), 1-10.

[20] Rodley, L., 'Tha Art and Architecture of Alexios I Komnenos', Alexios I Komnenos papers, edited by Margaret Mullett and Dion Smythe (Belfast, 1996), 339-358.

[21] Roche, J. T., 'In the Wake of Mantzikert: The First Crusade and the Alexian Reconquest of WesternAnatolia', History, Vol. 94, No. 2 (314) (2009), 135-153.

[22] Treadgold, W., 'The Persistence of Byzantium', The Wilson Quarterly (1976-), Vol. 22, No. 4 (1998), 66-91.

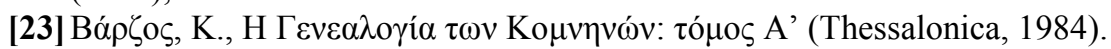

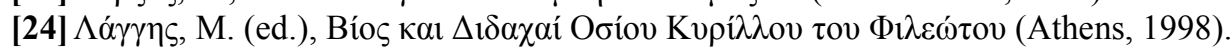

